\title{
Anion Exchange Membrane Soil Nitrate Predicts Turfgrass Color and Yield
}

\author{
Salvatore S. Mangiafico and Karl Guillard*
}

\begin{abstract}
Desirable nitrogen (N) management practices for turfgrass supply sufficient $\mathbf{N}$ for high quality turf while limiting excess soil $\mathbf{N}$. Previous studies suggested the potential of anion exchange membranes (AEMs) for predicting turfgrass color, quality, or yield. However, these studies suggested a wide range of critical soil nitrate-nitrogen $\left(\mathrm{NO}_{3}-\mathrm{N}\right)$ values across sample dates. A field experiment, in randomized complete block design with treatments consisting of nine $\mathrm{N}$ application rates, was conducted on a mixed species cool-season turfgrass lawn across two growing seasons. Every 2 wk from May to October, turfgrass color was assessed with three different reflectance meters, and soil $\mathrm{NO}_{3}-\mathrm{N}$ was measured with in situ AEMs. Cate-Nelson models were developed comparing relative reflectance value and yield to AEM desorbed soil $\mathrm{NO}_{3}-\mathrm{N}$ pooled across all sample dates. These models predicted critical AEM soil $\mathrm{NO}_{3}-\mathrm{N}$ values from 0.45 to $1.4 \mu \mathrm{g} \mathrm{cm}^{-2} \mathrm{~d}^{-1}$. Turf had a low probability of further positive response to $\mathrm{AEM}$ soil $\mathrm{NO}_{3}-\mathrm{N}$ greater than these critical values. These results suggest that soil $\mathrm{NO}_{3}-\mathrm{N}$ critical values from AEMs may be applicable across sample dates and years and may serve to guide $\mathrm{N}$ fertilization to limit excess soil $\mathrm{NO}_{3}-\mathrm{N}$.
\end{abstract}

\begin{abstract}
A ESTHETIC and functional considerations for turf management necessitate the application of $\mathrm{N}$ sufficient to achieve high quality turf, whereas environmental concerns require limiting the accumulation of excess soil $\mathrm{NO}_{3}-\mathrm{N}$, which may be lost by leaching. Nitrogen fertilizer applications to turfgrass are typically guided by predetermined schedules and rates or by improvements in visual quality. Scheduled applications and rates, however, cannot take into account plant available $\mathrm{N}$ added to the soil by mineralization of soil organic matter, clippings, or residual mineral $\mathrm{N}$ from previous applications. Scheduled applications coupled with substantial residual or mineralized soil $\mathrm{N}$ might cause the accumulation of excess soil $\mathrm{N}$ and increase the risk of substantial $\mathrm{N}$ leaching (Kopp and Guillard, 2005). It would be desirable, therefore, to make $\mathrm{N}$ application recommendations according to measured soil N. However, no soil test for $\mathrm{N}$ is commonly used for turfgrass in humid climates.

Because some soil $\mathrm{N}$ fractions will be converted to $\mathrm{NO}_{3}-\mathrm{N}$ under common turfgrass growing conditions, soil $\mathrm{NO}_{3}-\mathrm{N}$ may serve as an indicator of soil $\mathrm{N}$ sufficiency for high turfgrass quality. Soil $\mathrm{NH}_{4}-\mathrm{N}$ is also available to turf plants. However, studies predicting corn (Zea mays L.) yield with measured soil $\mathrm{N}$ found little improvement in the ability to separate $\mathrm{N}$ responsive from $\mathrm{N}$ unresponsive sites when soil $\mathrm{NH}_{4}-\mathrm{N}$ and $\mathrm{NO}_{3}-\mathrm{N}$ concentrations were used, as compared with $\mathrm{NO}_{3}-\mathrm{N}$ only
\end{abstract}

Dep. of Plant Science, Unit 4067, University of Connecticut, 1376 Storrs Road, Storrs, CT 06269-4067. Received 17 June 2005. *Corresponding author (karl.guillard@uconn.edu).

Published in Crop Sci. 46:569-577 (2006).

Turfgrass Science

doi:10.2135/cropsci2005.06-0136

(c) Crop Science Society of America

677 S. Segoe Rd., Madison, WI 53711 USA
(Blackmer et al., 1989; Binford et al., 1992; Morris et al., 1993; Sims et al., 1995).

Anion exchange membranes can be used to measure available soil $\mathrm{NO}_{3}-\mathrm{N}$. Soil $\mathrm{NO}_{3}-\mathrm{N}$ desorbed from AEMs has been correlated with $\mathrm{NO}_{3}-\mathrm{N}$ obtained with traditional soil extractions across a variety of locations, soils, and crops (Qian et al., 1992; Pare et al., 1995; Subler et al., 1995; Ziadi et al., 1999), with the suggestion that soil $\mathrm{NO}_{3}-\mathrm{N}$ measurements with AEMs may be more sensitive than those with traditional soil extractions (Pare et al., 1995; Wander et al., 1995).

Desorbed soil $\mathrm{NO}_{3}-\mathrm{N}$ from AEMs has been correlated with yield in perennial grassland (Collins and Allinson, 1999) and clipping yield, visual quality, and light reflectance measurement in turf (Kopp and Guillard, 2002; Mangiafico and Guillard, 2005). In these studies, yield, light reflectance, and quality measurements were related to AEM desorbed soil $\mathrm{NO}_{3}-\mathrm{N}$ with linear plateau, quadratic plateau, or Cate-Nelson models. These models predicted critical values of soil $\mathrm{NO}_{3}-\mathrm{N}$ desorbed from AEMs. The grasses had a low probability of further positive response to AEM soil $\mathrm{NO}_{3}-\mathrm{N}$ values greater than these critical values. Collins and Allinson (1999) reported critical values of AEM desorbed soil $\mathrm{NO}_{3}-\mathrm{N}$ between 0.22 and $11 \mu \mathrm{g} \mathrm{cm}^{-2} \mathrm{~d}^{-1}$ for perennial grassland yield by harvest period within two sites. Kopp and Guillard (2002) reported critical values between 0.35 and $26 \mu \mathrm{g} \mathrm{cm}^{-2} \mathrm{~d}^{-1}$ for quadratic response plateau models of turfgrass quality by assessment date within $2 \mathrm{yr}$ and two sites, and between 0.08 and $20 \mu \mathrm{g} \mathrm{cm}^{-2} \mathrm{~d}^{-1}$ for CateNelson models. Mangiafico and Guillard (2005) reported critical values between 0.31 and $0.43 \mu \mathrm{g} \mathrm{cm}^{-2} \mathrm{~d}^{-1}$ for linear plateau models for reflectance and yield data pooled across $2 \mathrm{yr}$. While these studies demonstrate the potential of the AEM technique to serve as a predictor of turfgrass yield, light reflectance measurement, and quality, the wide range of critical values reported by Collins and Allinson (1999) and Kopp and Guillard (2002) and the variation in reported critical values among studies fail to give a clear indication of an appropriate critical value across dates, sites, or conditions. Furthermore, only Mangiafico and Guillard (2005) gave critical values applicable across dates and years, which would be necessary if a soil test employing AEMs is to use critical values not specific for the date of sampling. However, they urged caution in extrapolating their reported critical values to all dates, because, by the design of their experiment, a wide range of soil $\mathrm{NO}_{3}-\mathrm{N}$ levels was not achieved on all sample dates.

Maximum achievable quality of turf is expected to vary across sample dates and across conditions or sites. If critical values are reported by sampling date, conditions specific to that date may result in unusually low or

Abbreviations: AEM, anion exchange membrane; CIE, Commission Internationale de l'Eclairage. 
unusually high critical values. Such critical values compiled over many dates may suggest a wide range of critical values, when in fact a smaller range may better describe a sufficient value for most conditions at that site. If all observations across sites or dates are pooled simply, variation in turf quality potential across dates produces models relating turf quality to soil $\mathrm{NO}_{3}-\mathrm{N}$ with low coefficients of determination $\left(r^{2}\right)$. This effect has been seen in models predicting corn yield in response to soil $\mathrm{NO}_{3}-\mathrm{N}$ concentrations across sites (Blackmer et al., 1989; Binford et al., 1992).

Simple averages across dates cannot be used to develop accurate critical values because these models cannot guarantee that these critical values would be applicable on all dates. This difficulty has been ameliorated in studies combining corn yield response to soil $\mathrm{NO}_{3}-\mathrm{N}$ concentrations across sites and years by converting absolute yields to relative yields for each siteyear. Relative yield values may be developed in relation to plateau values from quadratic response plateau models for each site-year (Fox et al., 1989; Binford et al., 1992; Sims et al., 1995) or from means of highest yields or application rates (Magdoff et al., 1984; Meisinger et al., 1992; Fox et al., 1993; Klausner et al., 1993; Morris et al., 1993; Sims et al., 1995). Collins and Allinson (2004) used relative yields by date and site that were then pooled to make models applicable across sites and years predicting perennial grassland yield in response to soil $\mathrm{NO}_{3}-\mathrm{N}$ concentrations. Similar procedures may be employed with turfgrass across sampling dates to develop relative yield or relative quality measurements. Because $\mathrm{NO}_{3}-\mathrm{N}$ is considered a soluble nutrient in the soil, linear plateau models may be most appropriate for modeling turf response on individual dates (Dahnke and Olson, 1990). If linear response or quadratic response plateau models are used for individual dates, critical values for each date may be retained to determine seasonal or environmental effects on critical values.

While subjective visual color and quality assessments are often used in turfgrass studies, objective color measurements may be made with hand held reflectance meters. Measurements from tristimulus chroma meters may be considered a direct measurement of turfgrass color and have been correlated with visual color assessments in bentgrass (Agrostis stolonifera L., A. capillaries L.) (Landschoot and Mancino, 2000) and also with chlorophyll concentration in clippings in a Kentucky bluegrass (Poa pratensis L.) and creeping red fescue (Festuca rubra L.) turf (Mangiafico and Guillard, 2005). Hand held reflectance meters designed for use in turf include the Spectrum CM1000 and Spectrum TCM500 (Spectrum Technologies, Inc. Plainfield, IL). Both meters measure light reflectance from a turf canopy and report an index value to quantify turf color. The TCM500 also reports individual values for red, green, and blue reflectance. Measurements from the CM1000 have been correlated to both leaf chlorophyll concentration and clipping yield in from a Kentucky bluegrass and creeping red fescue turf (Mangiafico and Guillard, 2005).

The purpose of this study was to further develop the use of AEMs to serve as predictors of available $\mathrm{N}$ suf- ficiency for turfgrass. By combining observations across sampling dates to develop critical values applicable across dates and years, we sought to avoid the limitations of Kopp and Guillard (2002) who reported a wide range of critical values by date. By using an experimental design that ensured a wide range of soil $\mathrm{NO}_{3}-\mathrm{N}$ levels throughout the growing season, we sought to avoid the limitations of Mangiafico and Guillard (2005) who advised caution in extrapolating their reported critical values to all dates in a growing season.

\section{MATERIALS AND METHODS}

\section{Experimental Design and Management}

A field experiment was conducted at the University of Connecticut Plant Science Teaching and Research Farm in Storrs, CT, USA, during two consecutive growing seasons (2003 and 2004). Twenty-seven field plots, each measuring 1.5 by $1.5 \mathrm{~m}$, were arranged in a randomized complete block design. Treatments consisted of nine rates of $\mathrm{N}$ application. Each month, from May to October, each plot received either 0, $4.9,9.8,19.6,29.4,39.1,48.9,73.4$, or $97.9 \mathrm{~kg} \mathrm{~N} \mathrm{ha}^{-1}$, for a total of between 0 and $587 \mathrm{~kg} \mathrm{~N} \mathrm{ha}{ }^{-1} \mathrm{yr}^{-1}$, applied as $\mathrm{NH}_{4} \mathrm{NO}_{3}$. Phosphorus $(\mathrm{P})$ as triple superphosphate and potassium $(\mathrm{K})$ as $\mathrm{KCl}$ were applied equally to all plots twice yearly according to soil test recommendations. A total of $174 \mathrm{~kg} \mathrm{P} \mathrm{ha}^{-1}$ and $252 \mathrm{~kg}$ $\mathrm{K} \mathrm{ha}^{-1}$ were applied during the experiment. Soil $\mathrm{pH}$ remained greater than 6.0 throughout the duration of the experiment without the addition of lime. Plots were mowed weekly during the growing season to a height of $4.5 \mathrm{~cm}$ and clippings remained on the plots. No artificial irrigation was added to supplement natural precipitation.

The site had been seeded to $36 \%$ creeping red fescue, $34 \%$ perennial ryegrass (Lolium perenne L.), and 30\% Kentucky bluegrass in 1999, and had remained in turf since then. The native soil was a Paxton fine sandy loam (Coarse-loamy, mixed, active, mesic Oxyaquic Dystrudepts). At the beginning of our experiment the surface mineral horizon of the soil had a $\mathrm{pH}$ of 6.1 , organic matter concentration of $52.9 \mathrm{~g} \mathrm{~kg}^{-1}$ by loss on ignition (Ball, 1964), and $1.32 \mathrm{mg} \mathrm{kg}^{-1} 0.01 M \mathrm{CaCl}_{2}$ extractable $\mathrm{NO}_{3}-\mathrm{N}$. Twice during the experiment, fenoxaprop \{2-[4-[(6-chloro-2-benzoxazolyl)oxy]phenoxy]propanoic acid\} and quinclorac (3,7-dichloro-8-quinolinecarboxylic acid) were applied to all plots to control annual grass weeds and broadleaf weeds, respectively.

\section{Anion Exchange Membranes}

Sampling of available soil $\mathrm{NO}_{3}-\mathrm{N}$ with AEM strips (Ionics, Inc. Watertown, MA) was conducted every 2 wk from May to October in 2003 and 2004 for a total of 23 sampling dates. Three AEM strips were used per plot. A large sheet of type204 vinyl copolymer AEM fabric was cut into strips measuring 7.6 tall by $2.5 \mathrm{~cm}$ wide. Strips were prepared by shaking in $0.5 \mathrm{M} \mathrm{HCl}$ for $5 \mathrm{~min}$, rinsing in deionized water, saturating with $\mathrm{Cl}^{-}$ions by shaking for $2 \mathrm{~h}$ in $1 \mathrm{M} \mathrm{NaCl}$, and rinsing again in deionized water. Shaking was performed in a reciprocal shaker (Eberbach Corp., Ann Arbor, MI) at 180 oscillations min ${ }^{-1}$. Strips were stored in deionized water until use.

Anion exchange membrane strips were inserted into the soil by making a slit at an angle of approximately $15^{\circ}$ from vertical with a mason's trowel. An AEM strip was inserted so that the top of the AEM was at the soil surface. Foot pressure was used to close the slit and ensure soil contact with the AEM. A monofilament line and flagging tape were attached to each 
AEM to facilitate removal. After 2 wk, the strips were removed and new strips were inserted. A new slit was made in a different location in the plot each time a new AEM was inserted. Upon removal from plots, the AEMs were rinsed lightly with deionized water and placed in 120-mL HDPE bottles containing $75 \mathrm{~mL}$ of $1 \mathrm{M} \mathrm{NaCl}$. The three strips from each plot were placed together in a single bottle on removal for extraction. These bottles were transported immediately to the laboratory and shaken for $1 \mathrm{~h}$ to desorb $\mathrm{NO}_{3}-\mathrm{N}$ from the AEMs. The resultant extracts were filtered through soil analysis papers having a retention range of 8 to $12 \mu \mathrm{m}$ (Schleicher and Schuell, Keene, $\mathrm{NH}$ ). Extracts were stored at $4^{\circ} \mathrm{C}$ for up to $48 \mathrm{~h}$, and were analyzed for $\mathrm{NO}_{3}-\mathrm{N}$ on a Scientific Instruments continuous flow analyzer (WESTCO, Danbury, CT) by the Griess-Ilosvay method (Keeney and Nelson, 1982).

\section{Turf Light Reflectance and Yield}

Light reflectance measurements of turf were taken with reflectance meters on 23 dates during the experiment corresponding to the $23 \mathrm{AEM}$ sampling dates. Commission Internationale de l'Eclairage (CIE) hue and CIE lightness measurements were taken with a Minolta CR400 chroma meter (Konica Minolta Holding, Inc., Tokyo, Japan). For each measurement, leaf blades were clipped from a small section of a plot and laid flat into an optically dense stack. A light reflectance measurement was taken in CIE L* a* b* coordinates at illuminant condition $\mathrm{C}$. The leaf blades were then randomly rearranged in the stack and another measurement was taken. This was repeated for five measurements for each plot. Values of $\mathrm{L}^{*}, \mathrm{a}^{*}$, and $\mathrm{b}^{*}$ were averaged per plot and converted to CIE hue and CIE lightness values (McGuire, 1992).

Light reflectance measurements were taken also with the Spectrum CM1000 and the Spectrum TCM500 reflectance meters on dates corresponding to the AEM sampling dates. Ten light reflectance measurements per plot of the turf canopy were taken with the Spectrum CM1000 and averaged per plot. All measurements were taken in full sun between $1000 \mathrm{~h}$ and $1400 \mathrm{~h}$ with the meter facing away from the sun. Measurements were taken holding the meter approximately $1.5 \mathrm{~m}$ from the turf canopy, yielding a circular area of evaluation of approximately $180 \mathrm{~cm}^{2}$ per measurement. With the Spectrum TCM500, five light reflectance measurements per plot of the turf canopy were taken and averaged per plot. This meter measured approximately $47 \mathrm{~cm}^{2}$ per measurement. Values for "index" and "red" from the TCM500 were retained for analysis. TCM500 "green" and "blue" values were not included in analyses only to keep the number of different reflectance measurements under consideration small. Clipping yield measurements were taken once per month from May to September each year for a total of 10 dates. Leaf blades were clipped from a $470-\mathrm{cm}^{2}$ area of a plot, dried at $71^{\circ} \mathrm{C}$ for $48 \mathrm{~h}$, and weighed.

\section{Statistical Analysis}

Mean values were calculated by treatment for each light reflectance and yield measurement across all dates. Mean values for AEM desorbed soil $\mathrm{NO}_{3}-\mathrm{N}$ were similarly calculated. Mean light reflectance and yield values were plotted against mean AEM soil $\mathrm{NO}_{3}-\mathrm{N}$ values, and a curvilinear Mitscherlich-Bray model $\left(y=a-b e^{-c x}\right)$ was fit to each (Dahnke and Olson, 1990).

Light reflectance measurements and clipping yield measurements were plotted against AEM desorbed soil $\mathrm{NO}_{3}-\mathrm{N}$ measurements of the corresponding date, and linear plateau models $[y=a+b x, x \leq(C L) ; y=a+b(C L), x>(C L)$, where $C L$ is the value on the $x$-axis where the segments join] were developed for each date. These linear plateau models suggest critical values of soil $\mathrm{NO}_{3}-\mathrm{N}$ greater than which turf light reflectance or yield does not increase and plateau values representing light reflectance or yield values at and greater than this critical value (Cerrato and Blackmer, 1990). When no significant linear plateau model was found, the value for the treatment with the highest value was used for the plateau value. Light reflectance and yield measurements were converted to relative values for that date by dividing each reflectance or yield value by the plateau value for that date. Relative values for each light reflectance or yield measurement were pooled across all dates and plotted against corresponding soil $\mathrm{NO}_{3}-\mathrm{N}$ values, so that Cate-Nelson models could be developed (Nelson and Anderson, 1977). A statistical procedure was used for each Cate-Nelson model to divide the data into two populations (Cate and Nelson, 1971) and thus suggest a critical AEM desorbed soil $\mathrm{NO}_{3}-\mathrm{N}$ value greater than which turf would have a low probability of response to higher soil $\mathrm{NO}_{3}-\mathrm{N}$ value. Critical light reflectance or yield values (y-axis) for these models were selected that minimized the sum of the errors for these models.

Critical values from dates on which there was a significant $(p<0.05)$ linear plateau model were pooled across quality and yield measurements and were grouped into three time periods: May and June, July and August, and September and October. These critical values were analyzed with analysis of variance (ANOVA) using a mixed effects model in which time period was a fixed effect and year was a random effect. The significance $(\alpha=0.05)$ of the random effects in the model was tested using $F$-tests in which the expected mean square values for the numerator and denominator differed by the variance component to be tested (Montgomery, 1997). Least square means were separated by applying a Tukey-Kramer adjustment $(\alpha=0.05)$. This mean separation test was chosen because it controls experiment-wise error rate, is conservative in identifying differences between means, and is commonly employed in agronomy research. Mean AEM soil $\mathrm{NO}_{3}-\mathrm{N}$ was plotted against $\mathrm{N}$ application rate and a model consisting of an exponential segment and a linear segment $\{y=a+b x, x>$ $(C L) ; y=k+(b+c) x+\mathrm{e}^{c[(C L)-x]}, x \leq(C L)$, where $k=a c$ (CL)- 1 and $C L$ is the value on the $x$-axis where the segments join\} was developed. This exponential function was chosen so that at the point $x=(C L)$, both functions would have the same values and slopes.

Because this study was conducted as a replicated experiment, treatment averages were used for all models (Gomez and Gomez, 1984). Segmented, linear plateau, and curvilinear models were generated with the NLIN procedure in the Statistical Analysis Software (SAS) package (SAS Institute, 1999). ANOVA was performed by the GLM procedure in SAS. Segmented, linear plateau, curvilinear, and ANOVA models were checked for homoscedasticity, normality of residuals, and independence of residuals (Tabachnick and Fidell, 2001).

\section{RESULTS AND DISCUSSION Turf Light Reflectance and Yield}

Significant $(p<0.05)$ Mitscherlich-Bray models were generated relating means for light reflectance and clipping yield to mean AEM desorbed soil $\mathrm{NO}_{3}-\mathrm{N}$ (Fig. 1). The shape of these models may be a result of averaging across dates data that would suggest linear plateau models on individual sample dates (Dahnke and Olson, 1990). The shapes of these models indicate that at high 

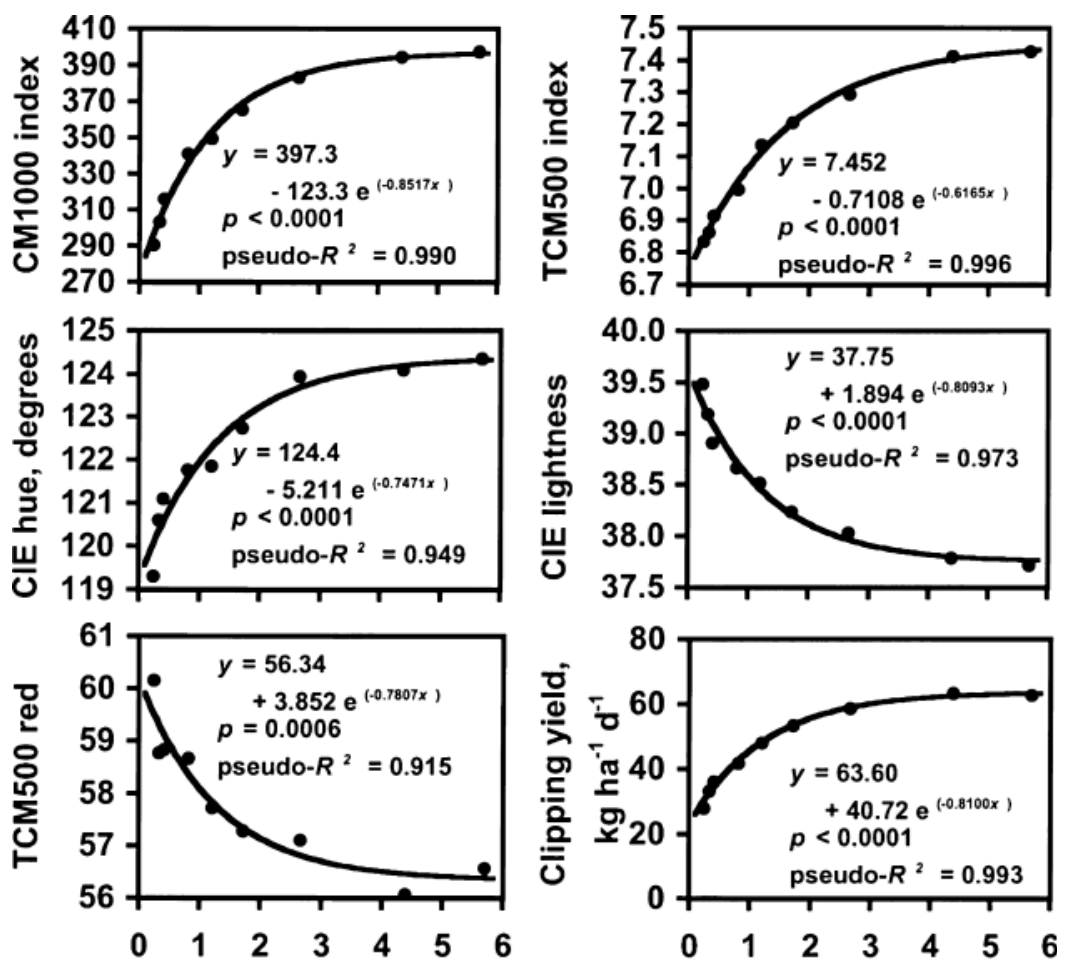

AEM desorbed $\mathrm{NO}_{3}-\mathrm{N}, \mu \mathrm{g} \mathrm{cm}^{-2} \mathrm{~d}^{-1}$

Fig. 1. Mean light reflectance measurements and clipping yield from turfgrass in relation to mean soil $\mathrm{NO}_{3}-\mathrm{N}$ desorbed from in situ anion exchange membranes. All measurements were averaged from 23 dates across two growing seasons. A fitted Mitscherlich-Bray model is shown for each plot.

soil $\mathrm{NO}_{3}-\mathrm{N}$ values, only small changes in light reflectance or yield are achieved by increasing soil $\mathrm{NO}_{3}-\mathrm{N}$ values. These models suggest that, for the conditions of our study, there is little benefit in terms of turf light reflectance or yield to fertilizing to a value greater than $3 \mu \mathrm{g}$ $\mathrm{cm}^{-2} \mathrm{~d}^{-1}$. However, because these plots indicate overall averages across two growing seasons, they cannot indicate a sufficient soil $\mathrm{NO}_{3}-\mathrm{N}$ value on any particular date.

Significant linear plateau models relating light reflectance measurements or yield to AEM desorbed $\mathrm{NO}_{3}-\mathrm{N}$ were found for 70 of 125 date-measurement combinations. As an example to illustrate turf response, these linear plateau models by sample date are shown for Spectrum CM1000 measurements only (Fig. 2). Both critical values and plateau values varied among sample dates within reflectance measurements and yield. Critical values ranged from 0.091 to $6.4 \mu \mathrm{g} \mathrm{cm}^{-2} \mathrm{~d}^{-1}$ across all significant linear plateau models. This range overlaps the ranges presented by Collins and Allinson (1999) for critical values from linear plateau and quadratic plateau models for yield of a perennial grassland by harvest periods, and by Kopp and Guillard (2002) for critical values from linear plateau and Cate-Nelson models for turfgrass quality by evaluation date. In general, though, the critical values from our study are lower. It was suggested that more intensely managed turfgrasses will require a higher soil $\mathrm{NO}_{3}-\mathrm{N}$ value to achieve maximum quality (Kopp and Guillard, 2002). On some sample dates, relationships other than linear plateau models were suggested by the data. For example, considering CM1000 index values (Fig. 2), CM1000 index increased with $\mathrm{AEM}$ soil $\mathrm{NO}_{3}-\mathrm{N}$ without a plateau on 17 July 2003, suggesting AEM soil $\mathrm{NO}_{3}-\mathrm{N}$ was not sufficient for maximum turfgrass reflectance for any treatment. There was no apparent response in CM1000 index with increasing AEM soil $\mathrm{NO}_{3}-\mathrm{N}$ on 9 Oct. 2003 or 23 Sept. 2004, possibly because turf color development was limited by other factors. The data on these sample dates suggest that there may be a range of turf responses to increasing AEM soil $\mathrm{NO}_{3}-\mathrm{N}$. However, no further modeling was attempted for these sample dates.

The median of the critical values from our models was $1.6 \mu \mathrm{g} \mathrm{NO}_{3}-\mathrm{N} \mathrm{cm}^{-2} \mathrm{~d}^{-1}$ (Fig. 3). A plot of the cumulative frequency of these critical values reveals that $80 \%$ are less than 3.3 and $90 \%$ are less than $4 \mu \mathrm{g} \mathrm{NO}_{3}-\mathrm{N} \mathrm{cm}^{-2} \mathrm{~d}^{-1}$ (Fig. 3). This distribution suggests that across light reflectance and yield measurements, there were few dates on which turf showed a response to fertilizing above 3.3 or $4 \mu \mathrm{g} \mathrm{cm}^{-2} \mathrm{~d}^{-1}$. This result is reflected in the plots of mean light reflectance and yield values in which there was little response above a mean soil $\mathrm{NO}_{3}-\mathrm{N}$ value of $3 \mu \mathrm{g} \mathrm{cm}^{-2} \mathrm{~d}^{-1}$ (Fig. 1).

Relative light reflectance and yield values were related to AEM desorbed $\mathrm{NO}_{3}-\mathrm{N}$ values with Cate-Nelson models (Fig. 4). These models pooled all values across dates and accounted for the critical values, the plateau values, and the rate of turfgrass response to increasing soil $\mathrm{NO}_{3}-\mathrm{N}$ value for individual dates. Each model indicated a critical value of soil $\mathrm{NO}_{3}-\mathrm{N}$ desorbed from AEMs. Turf had a low probability of further positive response to $\mathrm{AEM}$ soil $\mathrm{NO}_{3}-\mathrm{N}$ values greater than these critical values. Across light reflectance and yield measurements 

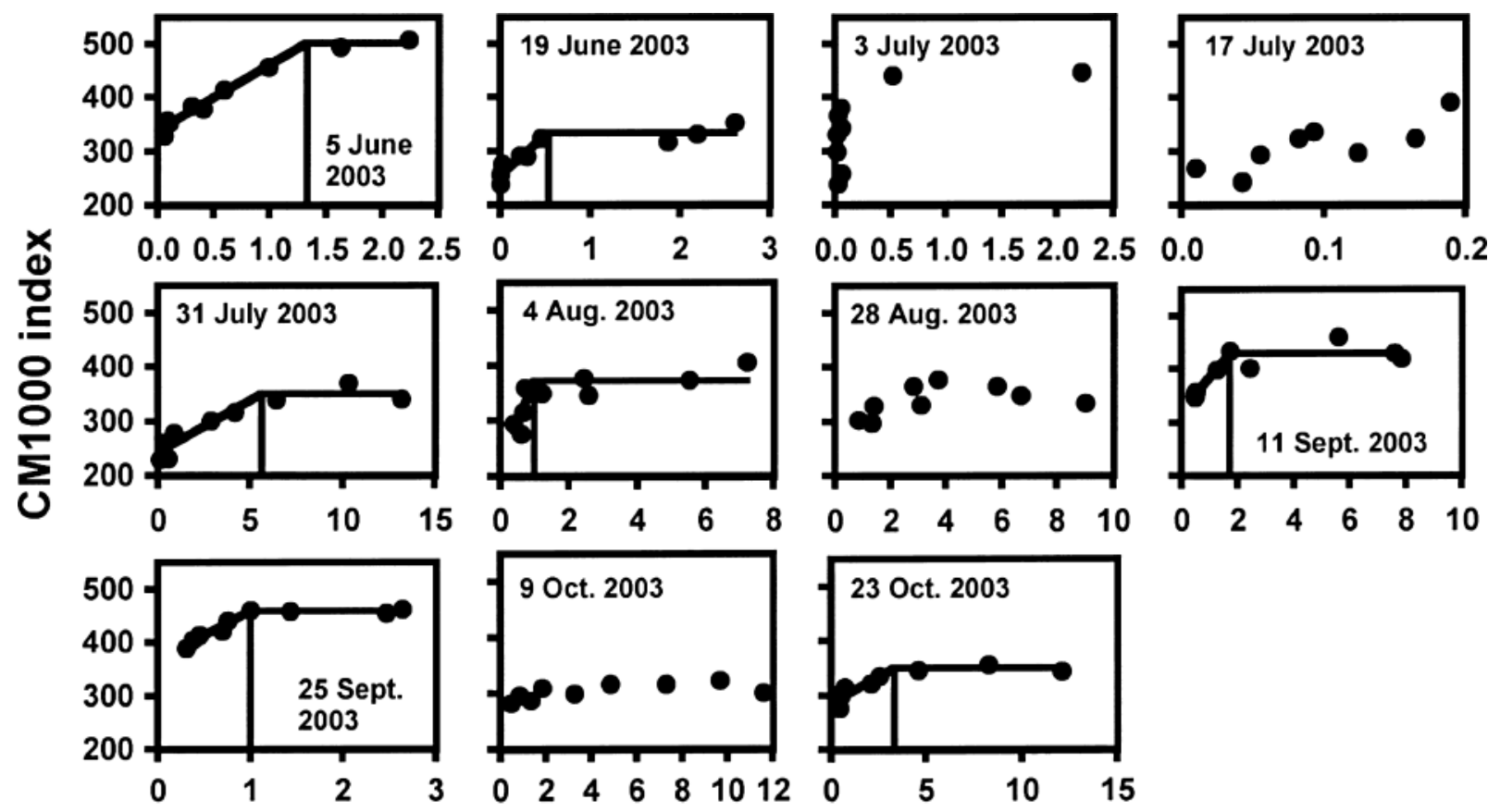

AEM desorbed $\mathrm{NO}_{3}-\mathrm{N}, \mu \mathrm{g} \mathrm{cm}^{-2} \mathrm{~d}^{-1}$
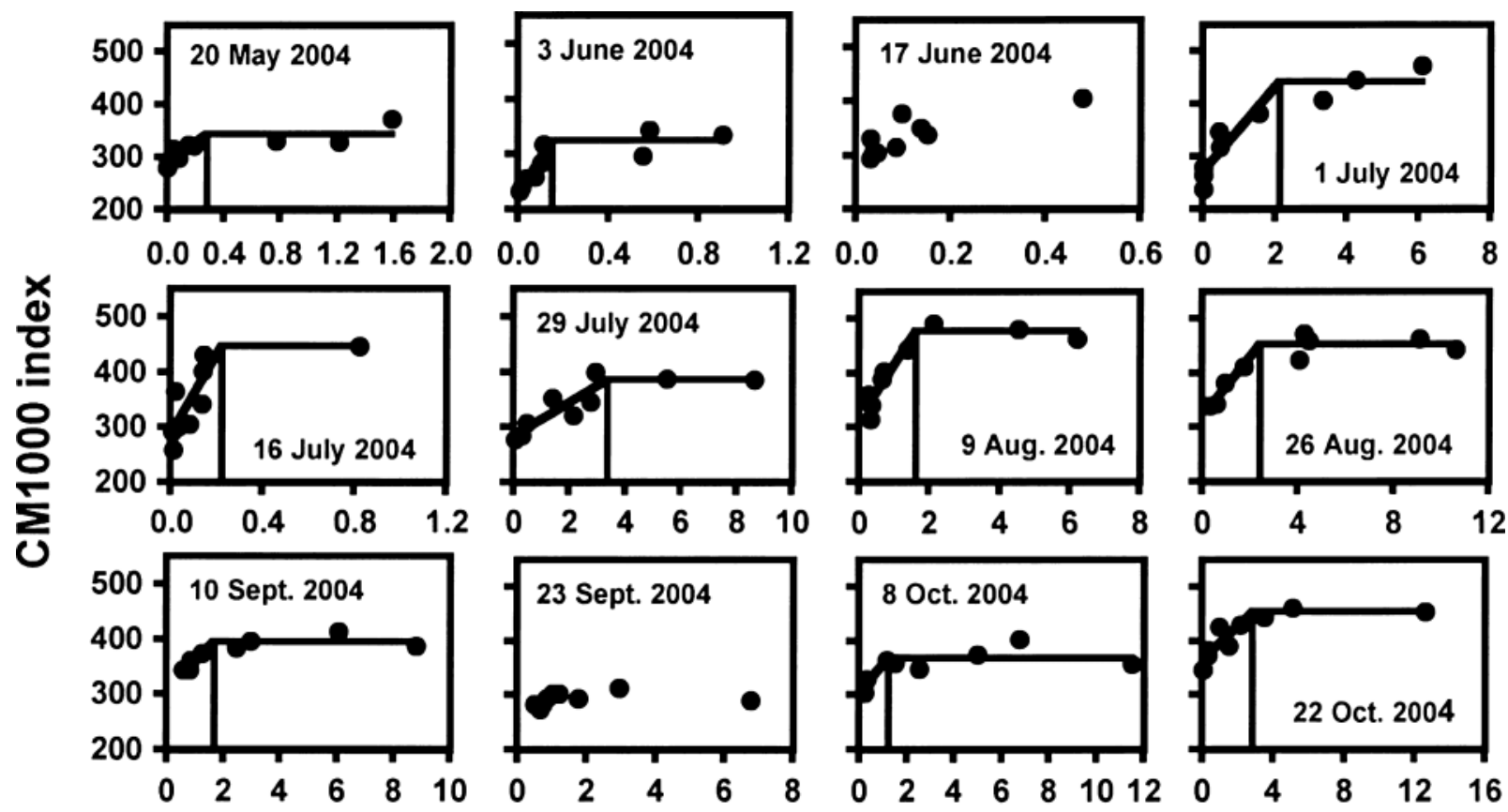

\section{AEM desorbed $\mathrm{NO}_{3}-\mathrm{N}, \mu \mathrm{g} \mathrm{cm} \mathrm{cd}^{-1}$}

Fig. 2. Light reflectance measurements from the Spectrum $\mathrm{CM1000}$ reflectance meter plotted against soil $\mathrm{NO}_{3}-\mathrm{N}$ desorbed from in situ anion exchange membranes, for each sample date. Significant $(p<0.05)$ linear plateau models are shown for dates on which such models were found. Vertical lines to the $\mathrm{x}$-axes indicate critical value of soil $\mathrm{NO}_{3}-\mathrm{N}$. Scale of $\mathrm{x}$-axes varies among plots.

critical values ranged from 0.45 to $1.4 \mu \mathrm{g} \mathrm{NO}_{3}-\mathrm{N} \mathrm{cm}^{-2}$ $\mathrm{d}^{-1}$. The critical values at the lower end of this range are similar to those from linear plateau models of values pooled across dates for turfgrass light reflectance and yield given by Mangiafico and Guillard (2005). The critical values from our Cate-Nelson models are less than those suggested by plots of mean values across dates (Fig. 1) and are lower than the median critical value of linear plateau models from individual dates (Fig. 3). However, observations in quadrant II of some Cate-Nelson plots suggest a critical value of 3 to $4 \mu \mathrm{g}$ $\mathrm{cm}^{-2} \mathrm{~d}^{-1}$ would better ensure a low probability of turf 


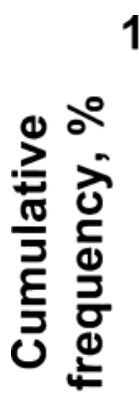

Fig. 3. Plot of cumulative frequency of critical values of soil $\mathrm{NO}_{3}-\mathrm{N}$ from linear plateau models. Critical values were pooled across five light reflectance measurements and clipping yield measurements and across all dates on which significant linear plateau models were found. Dashed lines indicate cumulative frequencies of 50,80 , and $90 \%$ and their respective critical values.

response to higher soil $\mathrm{NO}_{3}-\mathrm{N}$ values. Observations in quadrant I for our Cate-Nelson models, which represent model errors suggesting an overprediction of the critical value by the model, ranged from 3.9 to $18.4 \%$. Observations in quadrant II, which represent model errors suggesting an underprediction of the critical value by the model, ranged from 6.7 to $16.4 \%$. Total errors for these models ranged from 13.4 to $27.1 \%$ of observed values. This error rate is similar to that reported for CateNelson models relating turfgrass quality to AEM desorbed soil $\mathrm{NO}_{3}-\mathrm{N}$ (Kopp and Guillard, 2002) and is higher that that relating perennial grassland yield to soil $\mathrm{NO}_{3}-\mathrm{N}$ (Collins and Allinson, 2004).

The different models we used to combine data across dates suggested different critical values. In considering different models to predict soil $\mathrm{NO}_{3}-\mathrm{N}$ sufficiency in agronomic crops, a comparison of the costs of additional fertilization and the value of marginal crop yield may be made to determine which model best predicts economic efficiency (Cerrato and Blackmer, 1990). However, because it is difficult to assign economic value to turfgrass quality, it is not easy to determine which model gives the most appropriate estimate of critical values. Furthermore, determinations of economically optimum fertilization rates often ignore the costs associated with water quality impairment. Variations among critical values suggested by our different models might be considered in light of the balance between the goal of maximizing turf light reflectance and the goal of minimizing excess soil N. Because Cate-Nelson models indicate the reflectance and yield values relative to plateau values of all treatments on all dates, their use is appropriate for establishing critical soil $\mathrm{NO}_{3}-\mathrm{N}$ critical values greater than which the probability of significant turf response is low. These critical values (from 0.45-1.4 $\mu \mathrm{g} \mathrm{NO}_{3}-\mathrm{N} \mathrm{cm}^{-2}$ $\mathrm{d}^{-1}$ in our study), therefore, might represent a lower limit of soil $\mathrm{NO}_{3}-\mathrm{N}$ values that maximize turfgrass light re- flectance or yield. Soil $\mathrm{NO}_{3}-\mathrm{N}$ values from MitscherlichBray models of means across all dates (Fig. 1) above which there is little turf response (about $3 \mu \mathrm{g} \mathrm{NO}-\mathrm{N}$ $\mathrm{cm}^{-2} \mathrm{~d}^{-1}$ in our study) represent soil $\mathrm{NO}_{3}-\mathrm{N}$ values above which there was little response on any date or a response on few dates and therefore may represent an upper limit of $\mathrm{NO}_{3}-\mathrm{N}$ values to maximize turfgrass light reflectance or yield. Considering Mitscherlich-Bray models of average values, Cate-Nelson models of individual values, and the cumulative frequency distribution of critical values together, our turf with soil AEM values below $0.45 \mu \mathrm{g} \mathrm{NO}_{3}-\mathrm{N} \mathrm{cm}^{-2} \mathrm{~d}^{-1}$ were likely to be responsive to additional $\mathrm{N}$ application, and those with soil AEM values greater than $3 \mu \mathrm{g} \mathrm{NO}_{3}-\mathrm{N} \mathrm{cm}^{-2} \mathrm{~d}^{-1}$ were likely to be unresponsive to additional $\mathrm{N}$ application. Those with soil AEM values between these limits would be increasingly unlikely to be responsive to additional $\mathrm{N}$ application as soil AEM $\mathrm{NO}_{3}-\mathrm{N}$ increased. Practical considerations would recommend using several AEM strips in each sampled turf area to minimize misleading values due to spatial variability in soil $\mathrm{NO}_{3}-\mathrm{N}$. Multiple AEM samples could be bulked in the extraction step to minimize analysis costs. Based on our results, an AEM soil $\mathrm{NO}_{3}-\mathrm{N}$ value below $0.45 \mu \mathrm{g} \mathrm{cm}^{-2} \mathrm{~d}^{-1}$ would recommend a $\mathrm{N}$ fertilizer application. When water quality considerations are a priority, no application would be recommended when the AEM soil $\mathrm{NO}_{3}-\mathrm{N}$ value is greater than this value. In cases where maximizing turf quality is essential, a higher critical value could be used. Anion exchange membrane soil $\mathrm{NO}_{3}-\mathrm{N}$ values greater than $3 \mu \mathrm{g} \mathrm{cm}^{-2} \mathrm{~d}^{-1}$ would suggest an accumulation of soil $\mathrm{NO}_{3}-\mathrm{N}$ above turf needs, and a reevaluation of current $\mathrm{N}$ management of the turf area might be warranted. While results from our Cate-Nelson models suggest that an AEM soil $\mathrm{NO}_{3}-\mathrm{N}$ test will be fairly robust to differences among sample dates, prudence would suggest taking multiple samples separated in time by perhaps a week, if possible, before a management decision is made. Repeated AEM soil $\mathrm{NO}_{3}-\mathrm{N}$ measurements across a growing season could give insight into the merits of current $\mathrm{N}$ management practices at that site.

\section{Application Rate and AEM Soil $\mathrm{NO}_{3}-\mathbf{N}$}

Mean AEM desorbed soil $\mathrm{NO}_{3}-\mathrm{N}$ was significantly $(p<0.05)$ related to $\mathrm{N}$ application rate with a segmented model consisting of an exponential segment and a linear segment (Fig. 5). This result corroborates results of Collins and Allinson (1999) and Kopp and Guillard (2002) who found significant relationships between AEM desorbed soil $\mathrm{NO}_{3}-\mathrm{N}$ and $\mathrm{N}$ application rate. The reciprocal of the slope of the linear segment gives some indication of the amount of additional $\mathrm{N}$ fertilizer required to realize a marginal increase in AEM desorbed soil $\mathrm{NO}_{3}-\mathrm{N}$, about $15 \mathrm{~kg} \mathrm{~N} \mathrm{ha}^{-1} \mathrm{mo}^{-1}$ for each $\mu \mathrm{g}$ $\mathrm{cm}^{-2} \mathrm{~d}^{-1}$ when the AEM soil $\mathrm{NO}_{3}-\mathrm{N}$ value is greater than $1.6 \mu \mathrm{g} \mathrm{cm}^{-2} \mathrm{~d}^{-1}$, for the conditions of this experiment. Below this soil $\mathrm{NO}_{3}-\mathrm{N}$ value, the amount of applied $\mathrm{N}$ needed to increase $\mathrm{AEM}$ soil $\mathrm{NO}_{3}-\mathrm{N}$ would be greater. Because the data for this relationship are averaged over sample dates across two growing seasons, 

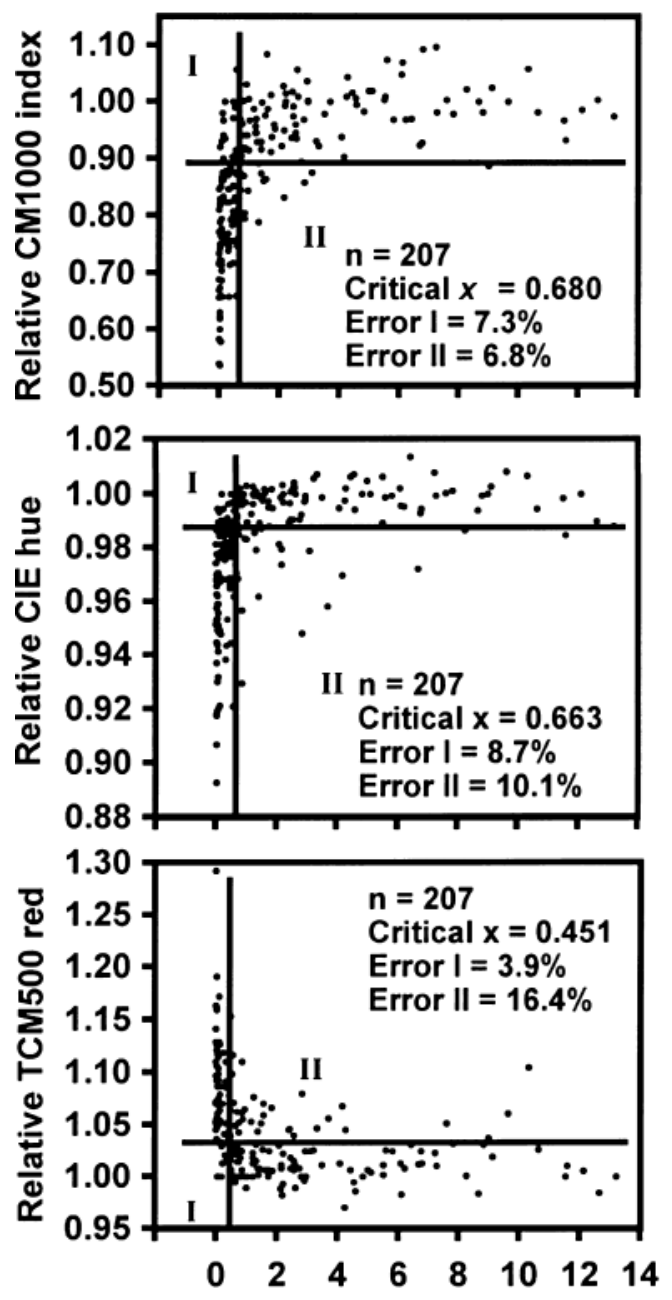

AEM desorbed $\mathrm{NO}_{3}-\mathrm{N}, \mu \mathrm{g} \mathrm{cm}^{-2} \mathrm{~d}^{-1}$
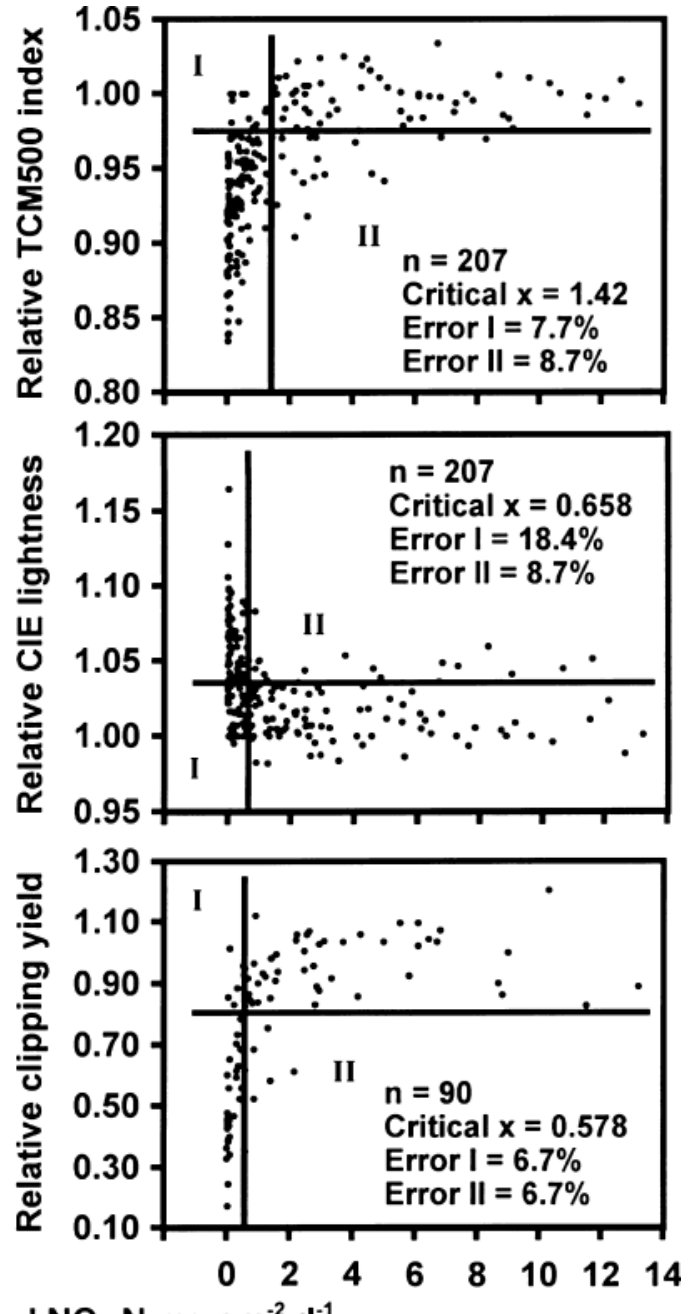

Fig. 4. Cate-Nelson models of relative light reflectance measurements and relative clipping yield for turfgrass in relation to soil $\mathrm{NO}_{3}-\mathrm{N}$ desorbed from in situ anion exchange membranes. Relative reflectance and yield values are expressed as a fraction of plateau values for reflectance or yield for each sample date. Vertical lines to the $\boldsymbol{x}$-axes represent critical $\boldsymbol{x}$ values which divide data into two populations, one which has a high probability of response to higher soil $\mathrm{NO}_{3}-\mathrm{N}$ values and one which has a low probability of response. Horizontal lines minimize data in quadrants I and II. Error I indicates the percentage of observations in quadrant I and represents an overprediction of the critical $x$ value. Error II indicates the percentage of observations in quadrant II and represents an underprediction of the critical $x$ value. Data are pooled from 23 dates across two growing seasons. Number of observations for each plot is given by $n$.

and the response of $\mathrm{AEM}$ desorbed $\mathrm{NO}_{3}-\mathrm{N}$ to $\mathrm{N}$ application rate will be affected by plant uptake, leaching losses, and microbial immobilization, this relationship may not hold on all sample dates. Tenth and ninetieth percentiles for the rate of response of AEM desorbed $\mathrm{NO}_{3}-\mathrm{N}$ to $\mathrm{N}$ application rate across all sample dates were 8.2 and $56 \mathrm{~kg} \mathrm{~N} \mathrm{ha}^{-1} \mathrm{mo}^{-1}$ for each $\mu \mathrm{g} \mathrm{cm}^{-2} \mathrm{~d}^{-1}$, respectively (data not shown).

A question of interest in the development of a soil test is whether the test can determine the amount of fertilizer to be applied when an application is recommended. This is a separate question from whether the test can determine if a fertilizer application is recommended. The wide range in the response of AEM desorbed $\mathrm{NO}_{3}-\mathrm{N}$ to $\mathrm{N}$ application rate across dates suggests that an AEM soil $\mathrm{NO}_{3}-\mathrm{N}$ test will be unable to predict well the amount of additional $\mathrm{N}$ application required to achieve some $\mathrm{AEM}$ soil $\mathrm{NO}_{3}-\mathrm{N}$ value unless an AEM soil values averaged across several sample dates are considered. Similarly, soil $\mathrm{NO}_{3}-\mathrm{N}$ concentrations were found to be unable to predict the amount of additional $\mathrm{N}$ application required to provide sufficient soil $\mathrm{N}$ for maximum corn yield (Fox et al., 1989; Klausner et al., 1993). Considering those data points with $\mathrm{AEM}$ soil $\mathrm{NO}_{3}-\mathrm{N}$ values below the critical value for each Cate-Nelson plot (Fig. 4), there was an apparent lack of relationship between turf reflectance or yield and $\mathrm{AEM}$ soil $\mathrm{NO}_{3}-\mathrm{N}$. This observation supports our suggestion that an AEM soil $\mathrm{NO}_{3}-\mathrm{N}$ test will be unable to predict well the amount of additional $\mathrm{N}$ application required to achieve the critical value of AEM soil $\mathrm{NO}_{3}-\mathrm{N}$.

\section{Seasonal Variations in Critical Levels}

The Mitscherlich-Bray and Cate-Nelson models developed in this study do not attempt to explain variation 
in critical values among sample dates. This variation may be caused by differences in temperature, precipitation, sunlight, or other factors that affect the $\mathrm{N}$ uptake and requirements of turf. These factors may occur either predictably through the growing season or from less predictable events. An ANOVA of critical values from linear plateau models for individual sample dates among reflectance and yield measurements showed that mean critical values were different among periods of the growing season and between years (Table 1 ). The lowest mean critical value, $0.73 \mu \mathrm{g} \mathrm{cm}^{-2} \mathrm{~d}^{-1}$, occurred for the May and June period. Mangiafico and Guillard (2005) similarly noted that some turf light reflectance values for May were greater than plateau values but at soil $\mathrm{NO}_{3}-\mathrm{N}$ values below critical soil $\mathrm{NO}_{3}-\mathrm{N}$ values. It may be that a moisture and temperature conditions in the spring are conducive to uptake of soil $\mathrm{NO}_{3}-\mathrm{N}$ by cool-season turf, so that lower $\mathrm{NO}_{3}-\mathrm{N}$ soil value is required for optimum light reflectance or growth. Alternatively, it may be that a lower soil $\mathrm{NO}_{3}-\mathrm{N}$ value is required for optimum light reflectance or growth because turf plants have stored $\mathrm{NO}_{3}-\mathrm{N}$ from the previous fall. The highest mean critical value of soil $\mathrm{NO}_{3}-\mathrm{N}, 3.0 \mu \mathrm{g} \mathrm{cm}^{-2} \mathrm{~d}^{-1}$, was for the July and August period. It may be that limited moisture and high temperatures during the summer limit cool-season turfgrass uptake of $\mathrm{NO}_{3}-\mathrm{N}$, so that high values of soil $\mathrm{NO}_{3}-\mathrm{N}$ are necessary for sufficient uptake for optimum light reflectance and that inefficient uptake results in more residual $\mathrm{NO}_{3}-\mathrm{N}$ in the soil. This will be the case if site conditions, such as turf stand age, soil organic matter, and amount of thatch do not allow for rapid net immobilization of applied $\mathrm{N}$. In this case, this result cautions against fertilizing to high soil $\mathrm{NO}_{3}-\mathrm{N}$ values to achieve optimum light reflectance in the summer, since

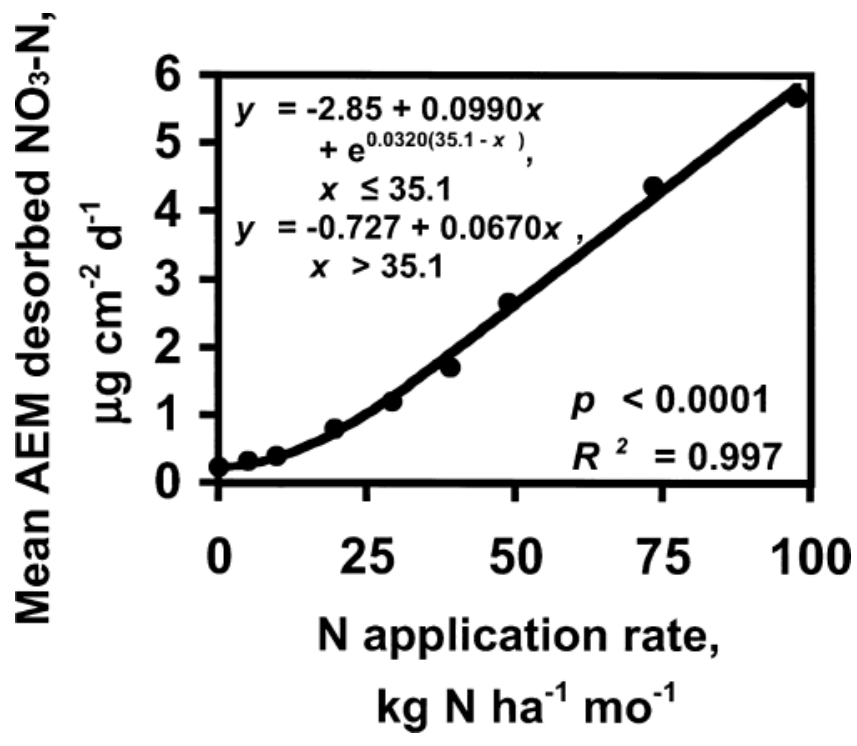

Fig. 5. Mean soil $\mathrm{NO}_{3}-\mathrm{N}$ desorbed from in situ anion exchange membranes in relation to $\mathrm{N}$ application rate for a mixed cool-season turf lawn grown on a fine sandy loam soil in Connecticut. Soil $\mathrm{NO}_{3}-\mathrm{N}$ values were averaged by treatment from 23 dates across two growing seasons. $\mathbf{N}$ was applied in 6 mo each growing season, May through October, for a total of between 0 and $587 \mathrm{~kg} \mathrm{ha}^{-1} \mathrm{yr}^{-1}$. A fitted model consisting of an exponential curve segment and a linear segment is shown.
Table 1. Analysis of variance and least square (LS) means for critical values of soil $\mathrm{NO}_{3}-\mathrm{N}$ desorbed from anion exchange membranes. Critical values predict plateau values for light reflectance or yield of turfgrass, and are pooled from $\mathbf{7 0}$ linear plateau models across two growing seasons in Connecticut.

\begin{tabular}{|c|c|c|c|}
\hline Period & \multicolumn{3}{|c|}{ LS mean critical value } \\
\hline & \multicolumn{3}{|c|}{$\mu \mathrm{g} \mathrm{NO}{ }_{3}-\mathrm{N} \mathrm{cm}^{-2} \mathrm{~d}^{-1}$} \\
\hline $\begin{array}{l}\text { May and June } \\
\text { July and August } \\
\text { September and October }\end{array}$ & \multicolumn{2}{|c|}{$\begin{array}{c}0.728 \mathrm{c} \dagger \\
2.99 \mathrm{a} \\
2.05 \mathrm{~b}\end{array}$} & \\
\hline Source of variation & df & $\boldsymbol{F}$ & $p$ value \\
\hline Period & 2 & 20.21 & $<\mathbf{0 . 0 0 0 1}$ \\
\hline Year & $\mathbf{1}$ & 4.81 & $\mathbf{0 . 0 3 1 9}$ \\
\hline Period $\times$ Year & 2 & 2.79 & 0.691 \\
\hline CV, \% & 59.0 & & \\
\hline
\end{tabular}

$\dagger$ Values followed by the same letter are not significantly different according to mean separation test with Tukey-Kramer adjustment $(\alpha=0.05)$.

the inability of cool-season turfgrass to efficiently utilize soil $\mathrm{NO}_{3}-\mathrm{N}$ will leave excess soil $\mathrm{NO}_{3}-\mathrm{N}$ which would be available for leaching during precipitation events.

\section{CONCLUSIONS}

Significant models relating turfgrass light reflectance and yield to values of soil $\mathrm{NO}_{3}-\mathrm{N}$ desorbed from AEMs were found. When data from all sample dates were pooled into Cate-Nelson models, turf had a low probability of further positive response to soil $\mathrm{NO}_{3}-\mathrm{N}$ values greater than the critical values suggested by these models. These results suggest that AEMs can be applied as a tool in $\mathrm{N}$ management of turfgrass and mitigate the concern that critical values of soil $\mathrm{NO}_{3}-\mathrm{N}$ for optimizing turf light reflectance vary widely by sample date. Mitscherlich-Bray models fitted to values averaged across sample dates suggested higher critical values than did Cate-Nelson models. Considering the models together, our turf with soil AEM values below $0.45 \mu \mathrm{g}$ $\mathrm{NO}_{3}-\mathrm{N} \mathrm{cm}^{-2} \mathrm{~d}^{-1}$ were likely to be responsive to additional $\mathrm{N}$ application, and those with soil AEM values greater than $3 \mu \mathrm{g} \mathrm{NO}_{3}-\mathrm{N} \mathrm{cm}^{-2} \mathrm{~d}^{-1}$ were likely to be unresponsive to additional $\mathrm{N}$ application. Use of values at the lower end of this range for a critical value would be more appropriate when minimizing excess soil $\mathrm{NO}_{3}-\mathrm{N}$ is a priority. Significant differences in critical values from linear plateau models were found among periods of the growing season and between years. This result suggests that better precision in recommended critical values could be achieved if seasonal factors such as temperature and precipitation are considered. Mean AEM desorbed soil $\mathrm{NO}_{3}-\mathrm{N}$ was related to $\mathrm{N}$ application rate. However, variations in the slope of this relationship across sample dates suggest that an AEM soil $\mathrm{NO}_{3}-\mathrm{N}$ test will be unable to predict well the amount of additional $\mathrm{N}$ application required even when it predicts an application is needed. This suggestion is supported by the lack of a relationship in Cate-Nelson models between turf reflectance or yield with soil AEM $\mathrm{NO}_{3}-\mathrm{N}$ when soil AEM $\mathrm{NO}_{3}-\mathrm{N}$ was below critical values. The results of our study are promising for the use of AEMs as a soil test for $\mathrm{NO}_{3}-\mathrm{N}$ for turfgrass to identify if turf will be likely or unlikely to respond to additional $\mathrm{N}$ application. 
However, all studies exploring this application have been performed in Connecticut with relatively similar soils and climate. Our study was conducted on a mixed species lawn. Because different turf species and cultivars may have different $\mathrm{N}$ requirements and use efficiencies, it is unclear how the critical values determined in this study would need to be adjusted for use in single species lawns or lawns with other species or cultivars. If this approach is to be viable, further study needs to be undertaken across a range of locations, soils, climates, and species.

\section{ACKNOWLEDGMENTS}

Funding for this research was supplied by the USDA Hatch Funds Act program, Northeastern Regional Association of State Agricultural Experiment Station Directors project NE187 "Best Management Practices for Turf Systems in the East," and the Connecticut Institute of Water Resources. We are grateful to Drs. Thomas F. Morris and John C. Clausen for their comments and suggestions for this paper.

\section{REFERENCES}

Ball, D.F. 1964. Loss-on-ignition as an estimate of organic matter and organic carbon in non-calcareous soils. J. Soil Sci. 15:84-92.

Binford, G.D., A.M. Blackmer, and M.E. Cerrato. 1992. Relationships between corn yields and soil nitrate in late spring. Agron. J. 84:53-59.

Blackmer, A.M., D. Pottker, M.E. Cerrato, and J. Webb. 1989. Correlations between soil nitrate concentrations in late spring and corn yields in Iowa. J. Prod. Agric. 2:103-109.

Cate, R.B., and L.A. Nelson. 1971. A simple statistical procedure for partitioning soil test correlation data into two classes. Soil Sci. Soc. Am. Proc. 35:658-660.

Cerrato, M.E., and A.M. Blackmer. 1990. Comparison of models for describing corn yield response to nitrogen fertilizer. Agron. J. 82: $138-143$.

Collins, S.A., and D.W. Allinson. 1999. Use of anion exchange membranes to assess nitrogen needs of perennial grasslands. Commun. Soil Sci. Plant Anal. 30:2267-2282.

Collins, S.A., and D.W. Allinson. 2004. Soil nitrate concentrations used to predict nitrogen sufficiency in relation to yield in perennial grasslands. Agron. J. 96:1272-1281.

Dahnke, W.C., and R.A. Olson. 1990. Soil test correlation, calibration, and recommendation. p. 45-71. In R.L. Westerman (ed.) Soil testing and plant analysis. 3rd ed. SSSA, Madison, WI.

Fox, R.H., G.W. Roth, K.V. Iversen, and W.P. Piekielek. 1989. Soil and tissue nitrogen compared for predicting soil nitrogen availability to corn. Agron. J. 81:971-974.

Fox, R.H., J.S. Shenk, W.P. Piekielek, M.O. Westerhaus, J.D. Toth, and K.E. Macneal. 1993. Comparison of near-infrared spectroscopy and other soil nitrogen availability quick tests for corn. Agron. J. 85: 1049-1053.

Gomez, K.A., and A.A. Gomez. 1984. Statistical procedures for agricultural research, 2nd ed. John Wiley \& Sons. New York.
Keeney, D.R., and D.W. Nelson. 1982. Nitrogen-inorganic forms. p. 643-698. In A.L. Page et al (ed.) Methods of soil analysis, 2nd ed., Part 2, Chemical and microbiological properties. ASA, SSSA, Madison, WI.

Klausner, S.D., W.S. Reid, and D.R. Bouldin. 1993. Relationship between late spring nitrate concentrations and corn yields in New York. J. Prod. Agric. 6:350-354.

Kopp, K.L., and K. Guillard. 2002. Relationship of turfgrass growth and quality to soil nitrate desorbed from anion exchange membranes. Crop Sci. 42:1232-1240.

Kopp, K.L., and K. Guillard. 2005. Clipping contributions to nitrate leaching from creeping bentgrass under varying irrigation and $\mathrm{N}$ rates. Int. Turfgrass Soc. Res. J. 10:80-85.

Landschoot, P.J., and C.F. Mancino. 2000. A comparison of visual vs. instrumental measurement of color differences in bentgrass turf. HortScience 35:914-916.

Magdoff, F.R., D. Ross, and J. Amadon. 1984. A soil test for nitrogen availability to corn. Soil Sci. Soc. Am. J. 48:1301-1304.

Mangiafico, S.S., and K. Guillard. 2005. Turfgrass reflectance measurements, chlorophyll, and soil nitrate desorbed from anion exchange membranes. Crop Sci. 45:259-265.

McGuire, R.G. 1992. Reporting of objective color measurements. HortScience 27:1254-1255.

Meisinger, J.J., V.A. Andel, J.S. Angle, B.E. O'Keefe, and C.M. Reynolds. 1992. Pre-sidedress soil nitrate test evaluation in Maryland. Soil Sci. Soc. Am. J. 56:1527-1534.

Montgomery, D.C. 1997. Design and Analysis of Experiments. 4th ed. John Wiley \& Sons. New York, NY.

Morris, T.F., A.M. Blackmer, and N.M. El-Hout. 1993. Optimal rates of nitrogen fertilization for first-year corn after alfalfa. J. Prod. Agric. 6:344-350.

Nelson, L.A., and R.L. Anderson. 1977. Partitioning of soil test-crop response probability. p. 19-37. In T.R. Peck et al (ed.) Soil testing: Correlating and interpreting the analytical results. ASA Spec. Publ. 29. ASA, CSSA, and SSSA. Madison, WI.

Pare, T., E.G. Gregorich, and B.H. Elliot. 1995. Comparison of soil nitrate extracted by potassium chloride and adsorbed on an anion exchange membrane in situ. Commun. Soil Sci. Plant Anal. 26: 883-898.

Qian, P., J.J. Schoenau, and W.Z. Huang. 1992. Use of ion exchange membranes in routine soil testing. Commun. Soil Sci. Plant Anal. 23:1791-1804.

SAS Institute Inc. 1999. SAS OnlineDoc, version 8. Cary, NC.

Sims, J.T., B.L. Vasilas, K.L. Gartley, B. Milliken, and V. Green. 1995. 1995. Evaluation of soil and plant nitrogen test for maize on manured soils of the Atlantic coastal plane. Agron. J. 87:213-222.

Subler, S., J.M. Blair, and C.A. Edwards. 1995. Using anion-exchange membranes to measure soil nitrate availability and net nitrification. Soil Biol. Biochem. 27:911-917.

Tabachnick, B.G., and S.F. Fidell. 2001. Using multivariate statistics, 4th ed. Allyn and Bacon. Boston, MA.

Wander, M.M., D.V. McCracken, L.M. Shuman, J.W. Johnson, and J.E. Box. 1995. Anion-exchange membranes used to assess management impacts on soil nitrate. Commun. Soil Sci. Plant Anal. 26: 2383-2390.

Ziadi, N., R.R. Simard, G. Allard, and J. Lafond. 1999. Field evaluation of anion exchange membranes as a $\mathrm{N}$ soil testing method for grasslands. Can. J. Soil Sci. 79:281-294. 